\title{
Identifying potential drugs that induce QT prolongation using electronic medical records
}

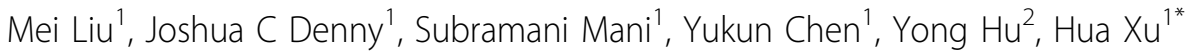 \\ From UT-ORNL-KBRIN Bioinformatics Summit 2010 \\ Cadiz, KY, USA. 19-21 March 2010
}

\section{Background}

A prolonged QT is a major risk factor for developing Torsades de Pointes, a potentially fatal cardiac dysrhythmia. The prolongation of QT interval may be due to adverse drug reactions. Many drugs such as haloperidol and methadone are known to prolong the QT interval. In effect, it is one of the most common reasons for drug withdrawal from the market [1]. Here, we propose to identify drugs that may promote $\mathrm{QT}$ prolongation using electronic medical records.

\section{Materials and methods}

As an ongoing effort in studying drug effects, Vanderbilt University Medical Center has constructed an anonymized database of medication orders and ECGs of all inpatients admitted for 2 to 30 days from 1999 to 2003. QT prolongations were detected from cardiologist-generated, free-text ECG impressions by combining negation detection and the natural language processor, KnowledgeMap concept identifier (KMCI) [2]. From this dataset, we designed our study to identify potential drugs that promote QT prolongations as their side effects by examining medications taken prior to the events. For instance, when QT prolongation is detected for a patient, drugs administered 72 hours prior are retrieved for further analysis. To determine which drug is more likely to be associated with the QT prolongation, we applied the chi-square $\left(\mathrm{X}^{2}\right)$ statistic.

\section{Results}

With a predefined level of significance at 0.001 (i.e. $\mathrm{X}^{2} \geq$ 10.827), 8 drugs showed significant signals, table 1 . Among them, 3 drugs have FDA-approved labels of QT prolongation as their known actions [3].

\footnotetext{
* Correspondence: hua.xu@vanderbilt.edu

'Department of Biomedical Informatics, Vanderbilt University, Nashville, TN 37232, USA
}

\begin{tabular}{|c|c|c|}
\hline Drug & Chi-square & Evidence \\
\hline Amiodarone & 39.21 & Known reaction \\
\hline $\begin{array}{l}\text { Potassium } \\
\text { supplements }\end{array}$ & 24.78 & $\begin{array}{l}\text { Treatment - typically given to people } \\
\text { with long QT intervals to keep it normal }\end{array}$ \\
\hline Procainamide & 22.11 & Known reaction \\
\hline Sotalol & 21.62 & Known reaction \\
\hline Warfarin & 18.42 & No evidence found \\
\hline Meperidine & 18.13 & No evidence found \\
\hline Oxycodone & 17.08 & No evidence found \\
\hline Promethazine & 12.90 & No evidence found \\
\hline
\end{tabular}

False positive predictions may be due to the fact that our study was based on hospitalized patients with acute diseases. Those patients may be taking a long list of medications and some drugs may interact with each other to contribute to the outcome.

\section{Conclusions}

The preliminary results showed that we are able to use inpatient medical records to detect drugs known to prolong QT intervals. For future study, it is crucial to consider patient existing conditions, health history, and contributions of other medications.

\section{Acknowledgements \\ This study was partially supported by NLM-NIH training grant 3T15LM007450-08S1 and grants from the NLM R01-LM007995-05 and NCI R01CA141307-01.}

\section{Author details}

'Department of Biomedical Informatics, Vanderbilt University, Nashville, TN 37232, USA. ${ }^{2}$ Department of E-commerce, Guangdong University of Foreign Studies, Guangzhou, Guangdong 510000, China.

Published: 23 July 2010 


\section{References}

1. Roden DM: Drug-induced prolongation of the QT interval. N Engl J Med 2004, 350(10):1013-1022.

2. Denny JC, Miller RA, Waitman LR, Peterson JF: Identifying QT prolongation from ECG impressions using a general-purpose Natural Language Processor. Int J Med Inform 2009, 78(Suppl 1):S34-S42.

3. Drugs that prolong the QT interval and/or induce Torsades dr Pointes ventricular arrhythmia.. [http://www.arizonacert.org/medical-pros/druglists/drug-lists.cfm].

doi:10.1186/1471-2105-11-S4-P2

Cite this article as: Liu et al: Identifying potential drugs that induce QT prolongation using electronic medical records. BMC Bioinformatics 2010 11(Suppl 4):P2.

\section{Submit your next manuscript to BioMed Central} and take full advantage of:

- Convenient online submission

- Thorough peer review

- No space constraints or color figure charges

- Immediate publication on acceptance

- Inclusion in PubMed, CAS, Scopus and Google Scholar

- Research which is freely available for redistribution

Submit your manuscript at www.biomedcentral.com/submit
C Biomed Central 